\title{
The Decision to Buy a Condominium in Minburi
}

\author{
Palakorn Liangchaisiri and Suthum Phongsamran
}

\begin{abstract}
Studying The decision to buy a condominium in Minburi. The purpose of this study was to investigate the decision making process of buying condominiums in Minburi area and the marketing mix factors that affected the decision to buy condominiums in Minburi. The study is a quantitative study. (Quantitative The questionnaire was used as a tool to collect data and statistics using frequency, percentage, mean, standard deviation (SD), t- ANOVA analysis using F-test (One-way ANOVA) and Regression Analysis The study indicated that Mostly male, age 21-30 years old, single and married status, bachelor degree, average monthly income is less than 20,000 baht and private employees, marketing mix factors. The decision to buy a condominium in Minburi is very high. The results of individual hypothesis testing have influenced the decision to purchase condominiums in terms of sex, age, status, education level. The average monthly income occupation varies. The decision to buy a condominium in the Minburi area. The statistical significance level was 0.05 . Marketing, personnel, physical and process factors influenced the decision to buy a condominium in Minburi. Suggestions from the study The decision to buy a condominium in Minburi. Condominium operators should focus on creating a product that meets the needs of the customer. The price of a condo is at a level that can be purchased. The distribution channel should promote the unique identity of the condominium. Security in the area of condominiums. Facilities Of the condominium To attract the decision to buy a condominium. In terms of marketing promotion, promotions and discounts on condo reservations are required. For condominiums, there is an option to purchase condominiums in Minburi.
\end{abstract}

Keywords - Condominium, Minburi

\section{INTRODUCTION}

Background and significance of the problem. At present, the working conditions of the present day people must compete with time always. Travel conditions that take a long trip. The population is increasing. The competition is high side. Therefore, daily life requires the best time management. Choosing housing is another factor that makes getting to work. However, the financial factor is the result of the decision to choose a residence to suit the financial liquidity of the individual. The condominium is popular with buyers. Both from the purchase to live. And for speculation The registration of transfer of residential condominiums in the period of 2007 2010 in Bangkok met to 30,676 units, 36,507 units, 44,692 units and 59,152 units, respectively (Government Housing Bank 2011). show that Consumers are increasingly demanding condominiums. As a result of the changing lifestyle, the cost of

Palakorn Liangchaisiri and Suthum Phongsamran, Graduate school of business administration, Kasembundit University, Bangkok. living is higher. And to invest in property that will have higher value in the long run. Especially along the route. The condominiums in good location have been completed and will be priced higher in the area around the city center and near the BTS line. The cost control and pricing. Study Requirement for Buying Decision The condominium is therefore essential to meet the needs of the population that needs housing. The condominium category is also useful to real estate developers to invest in. The condominium is very large. In terms of price, satisfaction and service to the buyer as well. To improve quality of life. And better housing quality in the future. Amidst the economic risks of several uncertainties. Therefore, the study participants are interested in studying factors that are related to purchasing decision. Condominium in Minburi area. Bangkok In order to bring the results of the study as a guide. Improve and plan the market to meet the needs of consumers who decide to buy a condominium in the future.

\section{PURPOSE OF STUDY}

To study the decision making process of buying condominiums in Minburi and to study marketing mix factors. That affects the decision to buy a condominium in Minburi.

\section{SCOPE OF STUDY}

The study investigated factors affecting the purchase of condominiums in Minburi area. Bangkok The theory, decision process and marketing mix. Product pricing channels. Marketing, human resources, physical and process aspects. Demographic data from 387 buyers in the Minburi area were selected. Time to study from January to June 2016.

\section{RESEARCH MYTHOLOGY}

How to precede Study on decision to buy a condominium in Minburi. Bangkok The objective of this study was to investigate the marketing mix factors affecting consumers 'choice of condominiums in Minburi district and to study consumers' decision to buy condominiums in Minburi. Quantitative study (Quantitative Research). The steps and details of the method of conducting the study as follows. Resources in the study include: Primary data is information obtained from data collection. The questionnaire was distributed to consumers who purchased a condominium in Minburi. Secondary Data is the study of books, textbooks, journals, related research and the Internet. The instrument used in this study was a questionnaire developed by the researcher to study the decision to buy a condominium in Minburi. Bangkok is divided into 3 sections.

- Part 1 questions about personal factors. Of the 
respondents, the nature of the question is multiple choice. The question is focused on the personal factors of the respondents, including gender, age, status, income, education and occupation. There are 6 questions.

- Part 2: Question on marketing mix factors affecting the decision to buy a condominium in Minburi Bangkok The questionnaire is an estimate. This is a 5-level ranking scale (Rating Scale). Product factor Price factor Channel factors The marketing, personnel, physical and process factors were 28 questions.

- Part 3 Questions about the decision to buy a condominium in Minburi Bangkok The questionnaire is an estimate. This is a 5-level ranking scale (Rating Scale). Purchase decision process At the stage of vision problems. Seeking information Alternative Assessment Purchase decision There are 20 questions.

The researchers conducted the data collection. The purpose of this study was to inform the sample. Describe the statement in the questionnaire. And the questionnaire was distributed to the sample. Data collection was done by the first 30 sets of questionnaires distributed to non-same samples. The reliability of the questionnaire was used to analyze the reliability of the questionnaire and to analyze the statistical data by computer. 385 people in Bangkok. Calculate the data obtained from the questionnaire by computer program by Percentage and Mean. Microsoft Excel is a software program for pie chart and BarChart. The results and the results from the chart are presented for analysis by the characteristics of the variables.

\section{STATISTICS USED IN DATA ANALYSIS}

Descriptive Statistics are frequency, percentage, mean, standard deviation (SD) to measure the distribution of data used to explain the data. Person of the respondent And marketing mix factors affecting the purchase of condominiums in Minburi. Inferential Statistics are used to test the hypothesis with t-test. ANOVA ANALYSIS F-test (One-wayANOVA) and Regression Analysis.

\section{THE RESULTS OF THE STUDY}

Personal factors found that the respondents The majority of them are female, aged between 21-30 years old. Marital status: Single, married with education level in upper secondary school / The income level is less than 20,000 baht and employs a private company.

The marketing mix and the decision to buy condominiums are at a high level. The details are as follows

\section{Marketing Mix Factor}

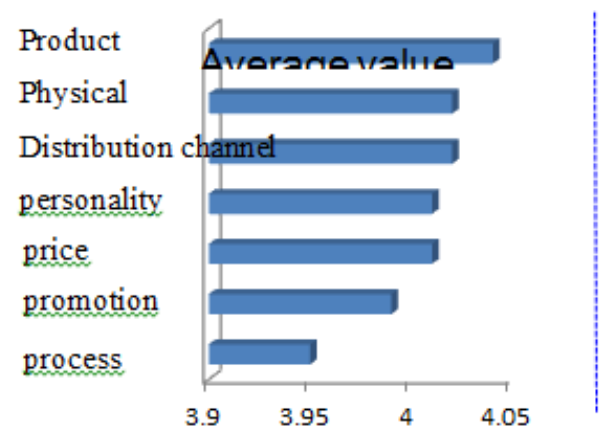

- Products From the study, it was found that the level of opinions on the marketing mix in terms of overall product quality was at a high level. The level of feedback is detailed. There are 4 amenities, including clubhouse, pool, layout, interior design, and condominium, size of the room, size and style of condominium. Modern

- Price from the study, it was found that the level of opinion on the marketing mix was at a high level. The level of feedback is detailed. At the very highest level, The price is suitable for the environment and location. And the interest rates are low, the sales price of the project is very worthwhile and The repayment schedule of the project is motivating.

- Distribution channel From the study, it was found that the level of opinions on marketing mix factors in the distribution channels was at a high level. The details of the level of agreement are very high. The location of the project is close to the transportation system such as MRT, Airport Link, location of the sales office in convenient contact with the project. Visit and have information that can. Attractiveness and There is a department store. And by the show. It's easy to make a purchase decision.

- Marketing promotion From the study, it was found that the level of opinions on marketing mix factors in marketing promotion was at the high level. The level of feedback is detailed. At the same level, there are 4 programs, including promotion program for customers who decide to book the project during the introductory period, the project is very motivating, the project with the partners to give special privileges to the customers. Electric Appliances such as air conditioners, microwave, attractive TVs, special discounts.

- Personnel According to the study, the level of opinions on marketing mix factors in personnel aspect was at a high level. The level of feedback is detailed. At the very agreeable level. The list consists of Salespeople are very good at getting customers. Sales staff to handle the document to the customer as well.Staff care after the sale of good and consistent and. Salespeople are explained and advised on the purchase of customers as well.

- Physical From the study, it was found that the level of opinions on the physical marketing mix was at a high level. The level of feedback is detailed. At the very conspicuous level 4, the surrounding area and interior are beautifully clean. And orderly Good enough parking spaces for the residents, the living space is appropriate for the price, security, strict security. 
- Process From the study, it was found that the level of opinions on the physical marketing mix was at a high level. The level of feedback is detailed. At the very highest level of approval, there are 4 documented projects on the project that allow customers to view the services they are applying for loans in the special offer of the project. Different types Get featured, have quick action. And effective.

\section{TEST RESULTS HYPOTHESIS}

Hypothesis 1: Different personal factors affect the decision to buy a condominium in Minburi area. Bangkok According to studies, it has been found that Personal factors regarding sex, age, status, income, education and occupation were not significantly different.

Hypothesis 2: Marketing mix factors influenced consumers' decision to buy condominiums in Minburi area. According to studies, it has been found that Marketing mix, product marketing, human resources, physical and process aspects. Influence the decision to buy a condominium. At 0.01 significant level

\section{SUMMARIZE AND DISCUSS THE RESULTS.}

The marketing mix of the products was at a high level. Corresponding to the research by Tosaporn mahamud (BE2555), the study was conducted to determine the factors affecting the purchase decision of Metro Sky Ratchada. The product marketing mix has influenced the decision to buy a condominium in the Metro Sky Ratchada project. The level of opinion is very agreeable. The overall marketing mix was at a high level. In addition to the research by Nuttapod (BE2555), the marketing mix factors affect the purchase decision of the condominium. Premium Bangkok The study indicated that Price marketing mix affects the decision to buy a condominium. Premium Bangkok The level of opinion is very agreeable.

\section{RECOMMENDATIONS FROM THE STUDY}

The decision to buy a condominium in Minburi. Condominium operators should focus on creating a product model. The price of a condo is at a level that can be purchased.
Promote the unique identity of the condominium. Security in the area of condominiums. Comfortable stay. Facilities of condominium Promotional Offers and Discounts on Condo Reservations For those who are interested in condominiums, there are options to purchase condominiums.

\section{SUGGESTIONS FOR THE NEXT STUDY}

Study quality of service of condo legal entity. And services in various areas. The quality of our services is satisfactory.

\section{REFERENCING OF BIOGRAPHY}

A conclusion section is usually required. Although a conclusion may review the main points of the paper, do not replicate the abstract as the conclusion. A conclusion might elaborate on the importance of the work or suggest applications and extensions.

\section{REFERENCES}

[1] Komsun bannasan (2012: abstracts) Study on Factors Affecting Consumer Buying Decision of Condominium after Flood in Bangkok And the metropolitan area. Project Case Study of Supalai Public Company Limited

[2] Tosaporn mahamud (2012: abstracts) Study on Factors Relating to Condominium Buying Behavior in Metro Sky Ratchada Project kasembundit University

[3] Natcha toonn (2012: Abstract) Study on Marketing Mix Factors Affecting Buying a Condominium Premium in Bangkok

[4] Aorapun panmomkong (2012: abstracts) Study of Thai consumers' behavior on buying condominiums in Amphoe Mueang Chiang Mai. Youtasart pantawaratan (2011: abstracts) Study on Factors of Buying Condominium in Thonburi Road. Bangkok

[5] Jintana srichaiya (2007: Abstract) Study on Consumer Expectations and Perceptions Affecting Purchasing Behavior Trends. LPN Development Public Company Limited. PUBLIC COMPANY LIMITED

[6] Tongscai sutung (2556: ABSTRACT) Study on the factors influencing the decision to buy a condominium to study factors of marketing mix, reputation and image. 